\title{
OBSERVATIONS WITHIN CAVITIES AT THE BED OF THE GLACIER ØSTERDALSISEN, NORWAY
}

\author{
By Wilfred H. Theakstone \\ (Department of Geography, University of Manchester, Manchester M ${ }_{3}$ 9PL, England)
}

\begin{abstract}
Basal ice at the glacier Østerdalsisen commonly deforms under stress within cavities at the glacier bed. Some ice subject to rapid strain, however, fails in a brittle manner. The creep-rate of basal ice is influenced by sediment particles within it, and by ice grain-size and structural anisotropy; a flow law for such ice has not been derived experimentally. Near the glacier bed, particles enclosed in ice may migrate as a result of stress concentration, bubbles may be flattened, and anisotropic structures may develop. Recrystallization leads to grain-size changes. Both regelation spicules and layers of regelation ice, generally thin, form within subglacial cavities but their occurrence is limited. Regelation-ice formation has a significant influence on the distribution of rock debris at the ceilings of subglacial cavities.

RÉsumé. Observation dans des cavités sous-glaciaires du glacier d'Osterdalsisen, Norvège. La glace du fond du glacier d'Østerdalsisen se déforme fréquemment sous l'action des contraintes en formant des cavités sousglaciaires. En quelques points où la glace est soumise à un effort rapide il peut, cependant, se produire des ruptures brutales. La vitesse de glissement de la glace de fond est influencée par les particules sédimentaires qu'elle inclut, ainsi que par la dimension et l'anisotropie structurelle des grains de glace. On n'a pas pu établir expérimentalement une loi d'écoulement pour une telle glace. Près du lit glaciaire, les particules incluses dans la glace peuvent migrer en raison de la concentration des efforts, les bulles peuvent être aplaties et des structures anisotropes se développer. La recristallisation conduit à des changements dans la dimension des grains. Des aiguilles de regel et des niveaux de glace de regel, généralement minces, se forment dans les cavités subglaciaires, mais leur abondance est limitée. La formation de glace de regel a une influence significative sur la distribution des débris minéraux au plafond des cavités sous-glaciaires.

Zusammenfassung. Beobachtungen in Hohlräumen am Untergrund des Osterdalsisen, Norwegen. Das Eis am Untergrund des Østerdalsisen verformt sich gewöhnlich unter Druck in Hohlräumen am Gletscherbett. Einiges Eis jedoch, das jähen Spannungen ausgesetzt ist, zerfällt spröde. Die Kriechgeschwindigkeit des Eises wird von seinem Gehalt an Sedimentpartikeln sowie von seiner Korngrösse und strukturellen Anisotropie beeinflusst; ein Fliessgesetz für solches Eis wurde experimentell noch nicht hergeleitet. In der Nähe des Gletscherbettes können vom Eis eingeschlossene Partikel infolge von Druckkonzentrationen wandern, Blasen können verflacht und anisotrope Strukturen entwickelt werden. Rekristallisation führt zu Änderungen der Korngrösse. In subglazialen Hohlräumen bilden sich sowohl Regelationsnadeln wie, im allgemeinen dünne, Schichten von wiedergefrorenem Eis, doch ist deren Vorkommen beschränkt. Die Bildung von wiedergefrorenem Eis hat wesentlichen Einfluss auf die Verteilung von Gesteinsschutt an der Decke subglazialer Hohlräume.
\end{abstract}

\section{INTRODUCTION}

Cavities are relatively common beneath glaciers. In addition to those which have a connection with the surface, others may exist at depth: many tunnels made in glaciers have revealed cavities at the bed (Waeber, I943; Haefeli, I95I; McCall, I952; Miller, I952; Kamb and LaChapelle, I964; Vivian and Bocquet, I973). Numerous cavities exist beneath the glacier Østerdalsisen, Norway. At its eastern margin, cavities formed down-glacier of each of a series of rock steps over which the glacier slides may be followed for distances of $30-80 \mathrm{~m}$, the limit of accessibility being associated with a glacier thickness of 50-6o m. The direction of glacier sliding is oblique to the orientation of the near-parallel steps. Having lost contact with its bed at the top of a step, the glacier arches down to the gently sloping floor below. Observations of the glacier bottom and bed have been made within these cavities annually since i 970 ; earlier studies were reported by Theakstone (1965, I966, I967) and Bennett (1968).

\section{Deformation of BASAL IGE}

Ice at the bed of a glacier commonly deforms. Fine details of the form of the rock surface over which it has moved may be preserved on the bottom of a glacier within subglacial cavities (Fig. I). The basal ice which forms the ceilings of such cavities may be sufficiently rigid 


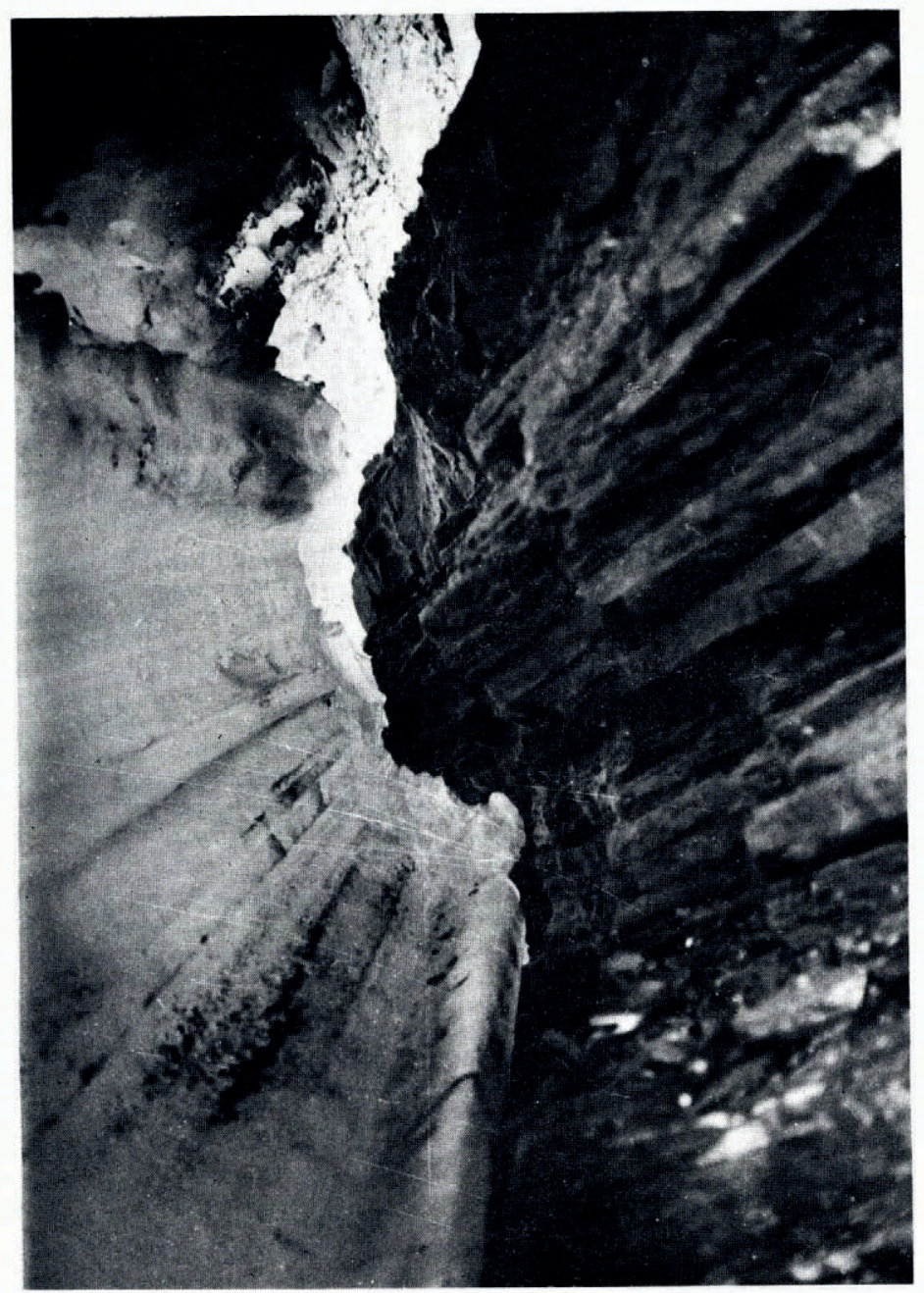

Fig. I. View up-glacier of ice at the bottom of Osterdalsisen moulded by the form of the rock surface (right) past which it has moved.

for fracture to occur but, on remaking contact with the bed at the down-stream end of the cavities, the ice may once more deform under stress. Highly stressed basal ice at such sites beneath Østerdalsisen tends to creep into large cavities, rotating as a result of the relative orientation of bed slope and ice-flow direction (Theakstone, I 966). The degree of deformation varies considerably from place to place beneath the glacier, reflecting local differences of conditions at the bed and marked departures from the mean stress.

The creep-rate of ice under a particular stress differs from one point to another at the bed of the glacier because of differences of its water, air and debris contents, grain-size characteristics, degree of anisotropy, and temperature. The textural and structural changes which occur as the ice deforms may themselves have a significant influence on its subsequent behaviour (Gold, r 1977). Observations related to some of these characteristics of basal ice at Østerdalsisen are reported below. 


\section{The Influence of INGLusions ON THE DEFoRMATION OF ICE}

Ice at the bed of Østerdalsisen deforms readily where the gas and water contents are high. Thin layers subject to high strain between ice trapped against the bed and more rapidly moving ice above are characterized by numerous air bubbles; deformation probably is facilitated by the low density of the bubble-rich ice. Paterson (1977) noted that laboratory ice without air bubbles was softer than glacier ice but he considered differences of grain-size were the most likely cause. Bubbly ice in the marginal zone of the Barnes Ice Cap deforms more rapidly than ice of relatively low bubble content (Hooke, I973). Carol (1945) reported that beneath Ober Grindelwaldgletscher, Switzerland, high local strain caused water-rich basal ice to flow more rapidly than that above. Duval (1977) demonstrated in the laboratory the marked influence of the water content of ice samples on their creep-rate.

As ice at or near the pressure-melting point is forced against the glacier bed, it deforms plastically; heat is produced and the melting point is depressed. Melting occurs within the ice, and water and air move towards the air/ice interface where pressure is lower. Unusually clear basal ice, almost free of air bubbles, present at several places beneath Østerdalsisen probably reflects the operation of such a process. Water and air also may be forced towards a thin water film between the bed and highly stressed ice.

The creep-rate of ice at or very close to the bed is likely to be influenced by the amount, nature, and distribution of small sediment particles within it. Whilst the degree of deformation of very dirty, fine-grained, bubble-free ice is much lower than that of clean ice subject to the same stress (Hooke and others, 1972), ice with a sand content of $3 \%$ or less by volume apparently deforms more readily than does clean ice (Goughnour and Andersland, i968). At the western margin of the Greenland ice sheet in the Thule area, fine material evenly

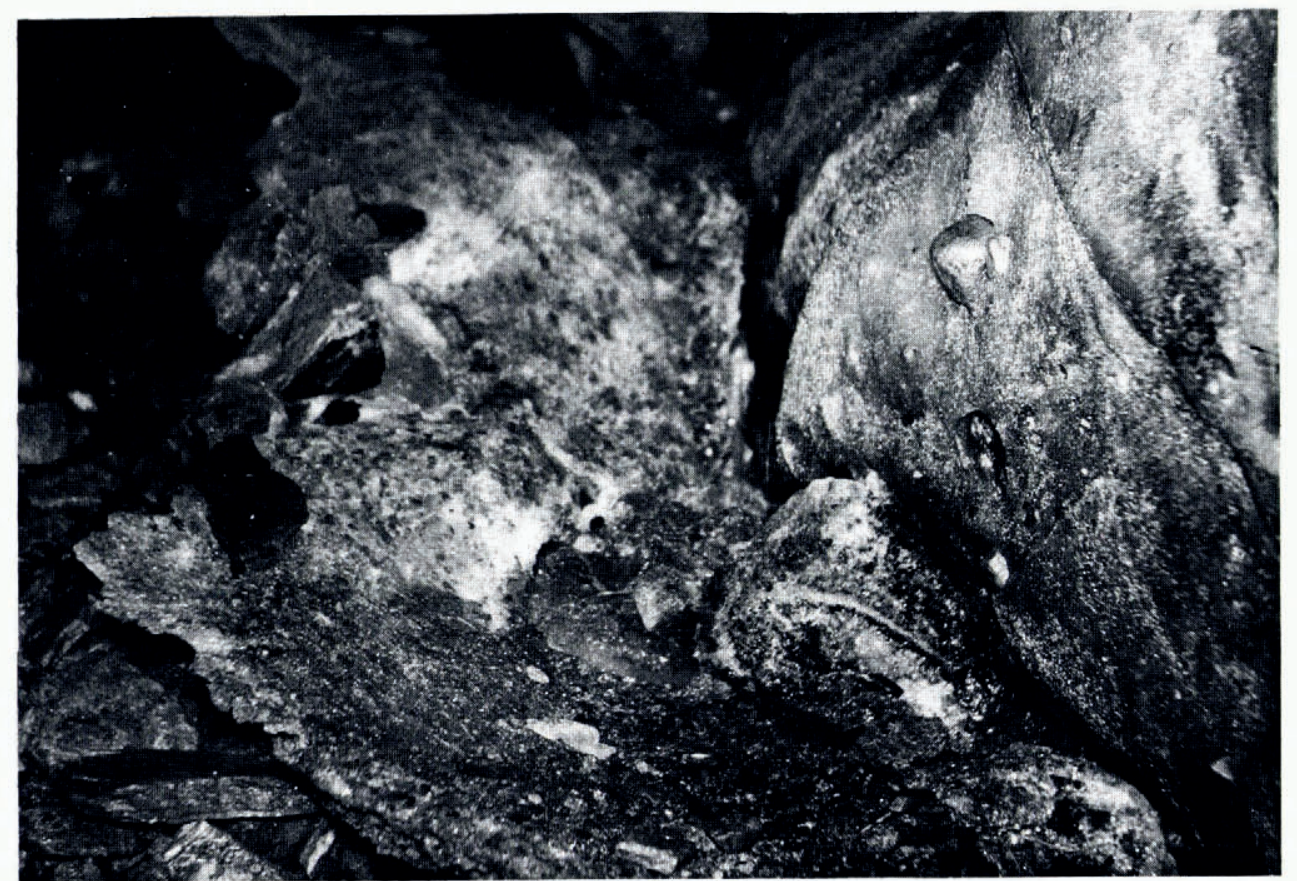

Fig. 2. Basal ice (right) deforming between the floor and the over-riding glacier. Ice formed by refreezing of water on the floor of the subglacial cavity (centre) itself is deforming in contact with basal glacier ice. Note the rock particles being expelled from the deforming ice, and the fracture plane (top right). 
distributed within the ice with few contacts between particles deforms faster than clean ice, whilst bands in which most of the inclusions are in contact with each other deform less readily than the surrounding ice (Swinzow, I962). The debris content of basal ice at Østerdalsisen is generally low and rarely more than $2 \%$ by volume. Together with inclusions of air and water, the predominantly fine particles render the ice relatively incompetent. Planar structures tend to form when such ice is subjected to high compressive stress or shear.

Fine debris particles in apparently foliated ice in contact with the bed of Østerdalsisen are concentrated into parallel or near-parallel layers, and air bubbles are flattened into plates roughly parallel with the bed; shearing taking place in a relatively thin zone causes both particle migration and distortion of bubbles within the basal ice. Commonly, bubbles in contact with debris particles in foliated basal ice contain some water, probably as a result of pressure melting at their periphery. Some bubbles in ice deforming against the bed appear to be elongated in the direction of extrusion but this is not always the case, perhaps because of the rapidly changing direction of extrusion as the ice rotates in a spiral-like manner.

Basal ice tends to deform against particles larger than gravel size at the glacier bed and ice may be crumpled against the up-stream side of stones. When ice flows over protuberances or loose stones at the bed, long grooves are left on the under surface of the glacier, as noted by Spencer ( 1887 ) beneath several Norwegian glaciers. The length of the groove extending from its down-stream side indicates the duration of the period for which a stone remained stationary before the shear stress exerted by the ice moving past it overcame the effects of friction between it and the bed. Grooves up to roo $\mathrm{cm}$ long have been observed at Østerdalsisen. Stones carried forward into the ceilings of subglacial cavities tend to be expelled there because of the differences of stress on their upper and lower surfaces (Vivian and Bocquet, I973). Large rock particles carried to the down-stream end of cavities may be expelled from ice deforming against the bed (Fig. 2).

\section{ThE EFFECT OF DEFORMATION ON ICE GRAIN-SIZE}

In places, very thin zones of extremely fine-grained ice can be seen at the upper surface of deforming ice in cavities beneath Østerdalsisen-where intense shearing is occurring. Similar mylonitized zones also occur occasionally within the ice. Liestøl (I950) reported a $50 \mathrm{~cm}$ thick zone of fine-grained fractured ice at the glacier bed, $30 \mathrm{~m}$ from the margin. Strain apparently is concentrated in such fine-grained zones, which may be particularly susceptible to grain-boundary creep, especially if the grains are flattened and intercrystalline films are present (Anderton, 1974).

Elsewhere beneath Østerdalsisen, recrystallization may result in the development of large grains; after stress release, the size of crystals in ice which has become detached from the glacier and is stagnating within cavities at the bed may increase to more than $80 \mathrm{~cm}^{2}$. Recrystallization may proceed rapidly, differences of grain-size between "active" ice and that from which it has separated along a fracture plane becoming noticeable within a few days.

\section{Fracture of BASAL ICE}

Fissures extending upwards from the glacier bottom may form in response to local stresses. If the curvature of a cavity ceiling changes from concave to convex near the down-glacier limit, local longitudinal extension occurs (Theakstone, I967; Vivian and Bocquet, I973). In places, this results in the formation of fractures at a high angle to the direction of glacier sliding. The distance to which fractures produced by bending propagate upwards is unknown; the few sites at which they form are close to the rock floor and relatively inaccessible. Fractures transverse to ice-flow direction at other parts of cavity ceilings are rare; over most of the ceiling, longitudinal strain-rates are low. Isolated lenses of fine-grained bubble-rich ice 
which extend upwards from cavity ceilings and are more-or-less perpendicular to flow lines may represent healed cracks which have moved from their site of origin further up-glacier.

During the ablation season, the glacier-sliding velocity in a zone at least $60 \mathrm{~m}$ wide decreases away from the border; shear strain-rates of the order of $0.135^{\mathrm{a}^{-1}}$ have been determined. Occasionally, shear deformation resulting from lateral differences of sliding velocity causes en échelon fissures to develop; since shear displacement varies across the affected zone, the fissures become distorted and tend to a sigmoidal shape.

Fracture planes dipping up-glacier may form in basal ice "trapped" against the glacier bed, the ice subject to rapid strain apparently failing in a brittle manner (Fig. 2). As ice above such a plane continues to move forward, that below may become completely detached from the glacier bottom. Some fracture planes are rotated as the enclosing ice continues to deform.

\section{Regelation ice in SUbglacial Gavities}

Various forms of ice resulting from refreezing of melt water exist in subglacial cavities at Østerdalsisen. Where the ice/rock contact is broken abruptly at the up-glacier limit of cavities, the under surface of the glacier may bear needle-like regelation spicules (Fig. 3). The spicules, which at Østerdalsisen are $1.5-3 \mathrm{~mm}$ in diameter and up to $12 \mathrm{~cm}$ long, generally are aligned in the direction of glacier sliding, although some have a less regular arrangement. They lengthen as sliding continues but eventually deform slowly, their outer ends peeling away from the glacier bottom (Fig. 3).

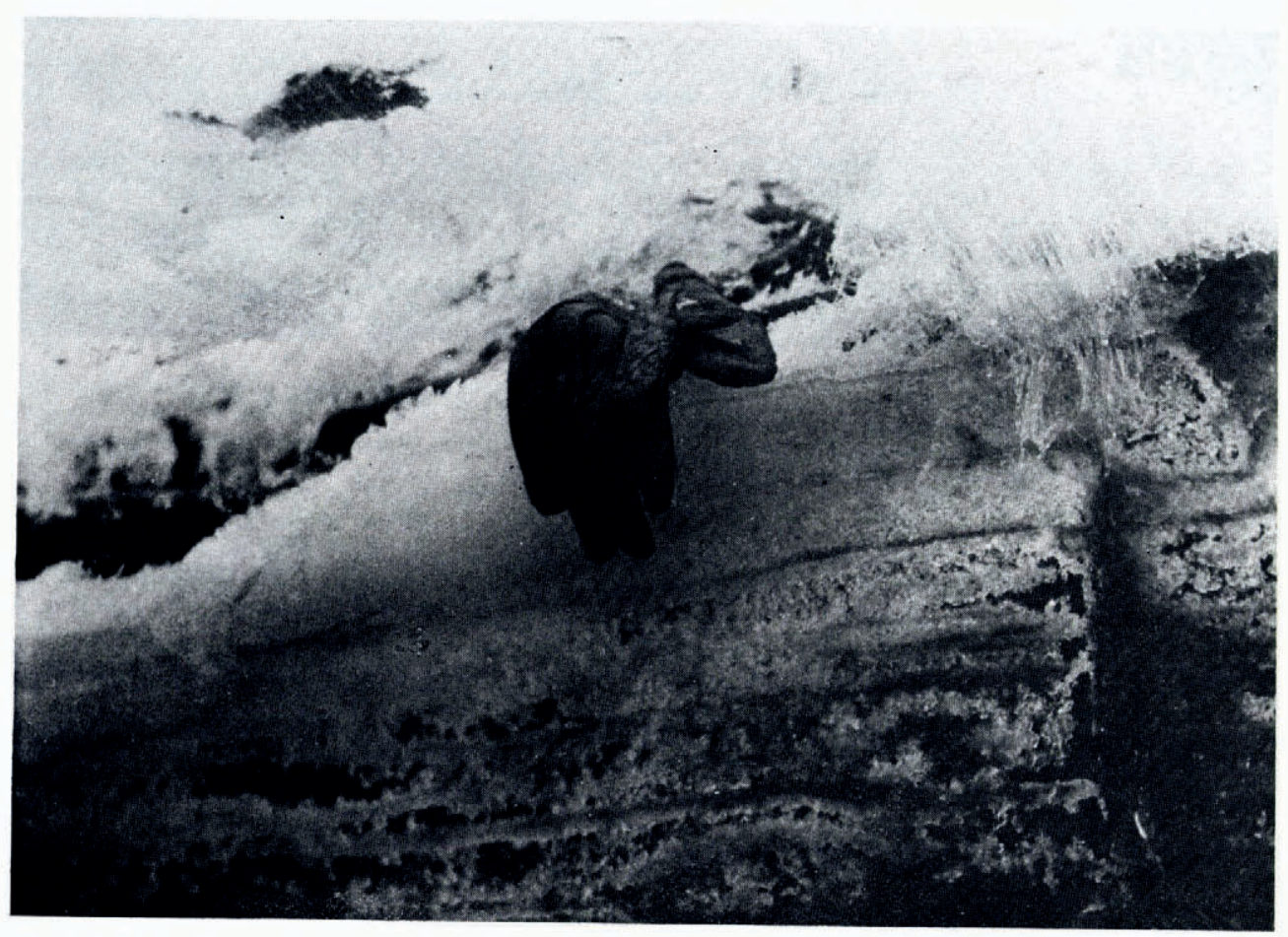

Fig. 3. Regelation spicules (top right) peeling from the glacier bottom at the ceiling of a subglacial cavity. Much of the upper part of the vertical rock cliff which forms the up-glacier limit of the cavity (bottom) is ice-coated. The glove marks the line along which the sliding glacier base (top left) loses contact with the bed. 
Parts of some cavity ceilings beneath Østerdalsisen have a striped appearance, zones of dirt-coated ice elongated along flow lines alternating with cleaner ice. Although the stripes may extend over the entire arch, the debris resonsible for them generally is thin. Melting occurs against slight elevations of the bed over which the glacier slides up-glacier of a cavity as a result of stress concentrations, and water and debris particles are forced towards adjacent depressions, where the water refreezes. Similar very thin debris-rich regelation layers may form where ice slides past a vertical or steeply inclined rock face (Fig. 4).

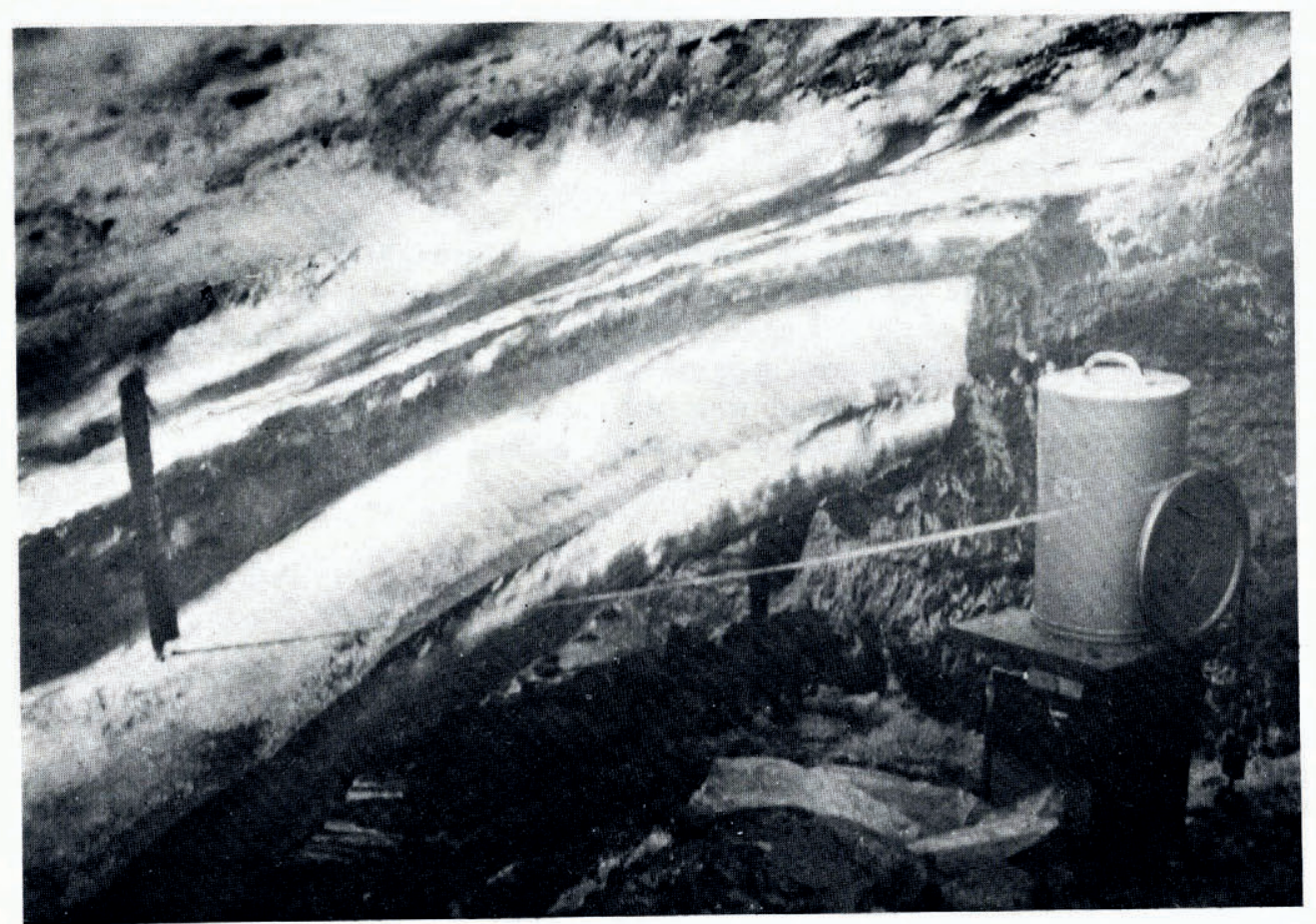

Fig. 4. Moulding of basal ice sliding past a near-vertical rock face (right) at the up-glacier end of a subglacial cavity. Superficial bands of fine rock particles, elongated along flow lines, alternate with cleaner ice at the bottom of the glacier. Basal ice is beginning to deform near the down-glacier ice/rock contact (bottom left). The instrument and peg were used in studies of basal movement of the glacier.

Regelation is responsible for the existence of occasional sheets of debris-rich ice at the glacier bottom. Although most accessible regelation layers beneath Østerdalsisen are less than $0.2 \mathrm{~m}$ thick, a few layers of much greater thickness-up to $0.8 \mathrm{~m}$ - exist. Such layers may persist through several successive cavities, their thickness depending on the balance between accretion by refreezing of water at the low-stress margins of the ice/bed contact area and loss by melting at the high-stress margins within each cavity. The sharply defined upper surface of a regelation layer may become partly detached from the overlying glacier ice, gradually peeling away over a period of several days. Considerable bending may occur before such a sheet fractures.

In many places, the upper part of a rock step at which a cavity forms is much less steep $\left(10-20^{\circ}\right)$ than the rest and the glacier commonly becomes detached from its bed o.6-0.7 $\mathrm{m}$ up-stream of the line of the step face. The short, relatively gentle rock slope generally is mudcoated or bears an abundance of fine rock particles and much water. At such sites, regelation 
may be restricted as melt-water drains away from the ice/rock contact. The spatially limited nature of regelation ice formation is indicated by the absence of a cover of regelation ice on pegs carried into cavities down-glacier of those in which they were inserted in the glacier base.

\section{OTHER SEGONDARY ICE FORMATIONS IN SUBGLAGIAL CAVITIES}

Most rock steps at the up-glacier side of subglacial cavities more than $10-15 \mathrm{~m}$ from the glacier margin bear a smooth coating of clear ice, the outer surface of which shows few signs of melting during the summer. Occasionally, water may be seen trickling down the rock face behind the ice. Some ice may be torn from the upper part of a near-vertical step by movement of the glacier to which it has become frozen, a process which may occur several times during a single winter (Bennett, I968). The separation between ice attached to the glacier bottom and the step from which it was torn indicates the distance moved by the glacier since the event (Drake and Ford, 1970). At the down-glacier ice/rock contact, ice on the cavity floor may freeze to the glacier bottom, buckling and sometimes fracturing under stress as glacier sliding continues.

Although the exposed surface of the ice extruded as long "rolls" along the down-glacier ice/rock contact generally is smooth, it does bear some accretions, principally floor ice which has frozen to it (Fig. 2). Some water appears to be squeezed out of the deforming ice, refreezing as a result of pressure reduction at the outer surface; ice deposited in this manner has been observed at the ceilings of cavities and tunnels beneath Blue Glacier (LaChapelle, I968; Knight and LaChapelle, I970) and Glacier d'Argentière, France (Souchez and others, I973; Vivian and Bocquet, 1973). Accretions of ice resulting from refreezing of extruded water are not common on the arching ceilings of cavities beneath Østerdalsisen.

\section{TEMPERATURES WITHIN SUBGLAGIAL GAVITIES}

Except where ice deforms under stress near the ice/rock contact, melting is insignificant at the ceilings of Østerdalsisen cavities distant from the glacier margin. The preservation of fragile regelation spicules and of finely moulded features on the glacier bottom is indicative of the ineffective nature of melting there. The detail impressed on ice as it slides over or past rock surfaces may be preserved on the cavity ceilings for distances equivalent to several years' glacier movement. The air temperature below Østerdalsisen does not rise much above $0^{\circ} \mathrm{C}$; direct recording has indicated that, $65 \mathrm{~m}$ from the glacier margin and $22 \mathrm{~m}$ below its level, the air temperature in summer is almost constant at about $-\mathrm{I} .0^{\circ} \mathrm{C}$. In winter, air at a temperature well below $0^{\circ} \mathrm{C}$ probably drains into the cavities. Little heat is supplied to the cavities from beyond the glacier margins and the temperature of much of the ice at cavity ceilings may be below the melting point, since the melting point of unstressed ice there is $0^{\circ} \mathrm{C}$, whilst the equilibrium temperature of ice some distance above the ceiling is lower; heat flows from the ceiling.

\section{Discussion}

Where the bed material is non-porous and not easily deformed, glacier sliding depends on temperature conditions and on the manner in which basal ice deforms under stress. Ice at the bottom of $\varnothing$ sterdalsisen includes variable amounts of air, water, and particulate matter, ice grain-size distributions differ markedly from one point to another and the basal ice generally is anisotropic. The nature and concentration of inclusions strongly influence the competence of basal ice layers and the hardness of the ice may be affected by small changes of temperature close to the melting point (Barnes and Tabor, 1966). 
A flow law for large $\left(c .8 .8 \times \mathrm{IO}^{-3} \mathrm{~m}^{3}\right)$ samples of glacier ice subject to uniaxial compression (maximum I.o bar) at the pressure-melting point was determined by Colbeck and Evans (1973). Although consistent in nature with Glen's quasi-viscous law for ice, it predicts strain-rates an order of magnitude larger than those found by Glen (1955) for stresses greater than I bar, probably because of temperature effects close to the melting point. However, the specimens tested by Colbeck and Evans (1973), composed of uniformly finegrained isotropic ice with evenly distributed air bubbles, are unlikely to represent the ice which deforms at or very close to the bed of a glacier. Until the response to stress of ice such as actually exists at glacier beds can be predicted from a well-tested flow law, an adequate theory of glacier sliding is unlikely to be developed.

\section{Acknowledgement}

Studies at Østerdalsisen have been supported by grants from the University of Manchester.

\section{REFERENGES}

Anderton, P. W. 1974. Ice fabrics and petrography, Meserve Glacier, Antarctica. Fournal of Glaciology, Vol. 13, No. 68 , p. $285-306$.

Barnes, P., and Tabor, D. I966. Plastic flow and pressure melting in the deformation of ice I. Nature, Vol. 2 ro, No. 5039, p. $878-82$.

Bennett, R. G. r968. Frost shatter and glacial erosion under the margins of Østerdalsisen, Svartisen. Norsk Geografisk Tidsskrift, Bd. 22, Ht. 3, p. 209-13.

Carol, H. 1945. Beschreibung einer Gruppe von Gletscherrandklüften am Obern Grindelwaldgletscher. Mitteilungen der Geographisch-Ethnographischen Gesellschaft in Zürich, Bd. 42, 1943-45, p. I 2-51.

Colbeck, S. C., and Evans, R. J. 1973. A flow law for temperate glacier ice. Fournal of Glaciology, Vol. 12, No. 64, p. $71-86$.

Drake, J. J., and Ford, D. C. 1970. Distorted ice stalactites as indicators of glacier movement. Fournal of Glaciology, Vol. 9, No. 56, p. $286-87$. [Letter.]

Duval, P. I 977 . The role of the water content on the creep rate of polycrystalline ice. [Union Géodésique et Géophysique Internationale. Association Internationale des Sciences Hydrologiques. Commission des Neiges et Glaces.] Symposium. Isotopes et impuretés dans les neiges et glaces. Actes du colloque de Grenoble, août/septembre 1975, p. 29-33. (IAHS-AISH Publication No. 118 .)

Glen, J. W. I955. The creep of polycrystalline ice. Proceedings of the Royal Society of London, Ser. A, Vol. 228, No. I $_{175}$, p. 5 19-38.

Gold, L. W. I977. Engineering properties of fresh-water ice. Journal of Glaciology, Vol. 19, No. 81, p. 197-2 1 2.

Goughnour, R. R., and Andersland, O. B. 1968. Mechanical properties of a sand-ice system. Proceedings of the American Society of Civil Engineers. Fournal of the Soil Mechanics and Foundations Division, Vol. 94, No. SM4, p. $923-50$.

Haefeli, R. I951. Some observations on glacier flow. Journal of Glaciology, Vol. I, No. 9, p. 496-500.

Hooke, R. L. 1973. Structure and flow in the margin of the Barnes Ice Cap, Baffin Island, N.W.T., Canada. Journal of Glaciology, Vol. 12, No. 66, p. 423-38.

Hooke, R. L., and others. 1972. Creep of ice containing dispersed fine sand, by R. L. Hooke, B. B. Dahlin, and M. T. Kauper. Fournal of Glaciology, Vol. I I, No. 63 , p. $327-36$.

Kamb, W. B., and LaChapelle, E. R. 1964. Direct observation of the mechanism of glacier sliding over bedrock. Journal of Glaciology, Vol. 5, No. 38, p. 1 $59-72$.

Knight, C. A., and LaChapelle, E. R. 1970. Further observations on stress-generated ice in the Blue Glacier, Washington, U.S.A. Fournal of Glaciology, Vol. 9, No. 55, p. 87-10 I .

LaChapelle, E. R. 1968. Stress-generated ice crystals in a nearly isothermal two-phase system. Fournal of Glaciology, Vol. 7, No. 50, p. $183-98$.

Liestøl, O. 1950. Ice crystal observations on Norwegian glaciers. Fournal of Glaciology, Vol. I, No. 8, p. 467 .

McCall, J. G. 1952. The internal structure of a cirque glacier: report on studies of the englacial movements and temperatures. Fournal of Glaciology, Vol. 2, No. 12, p. 122-31.

Miller, M. M. 1952. Glacier tunnel observations in Alaska. Journal of Glaciology, Vol. 2, No. 1 1, p. 69-7o. [Letter.]

Paterson, W. S. B. 1977. Secondary and tertiary creep of glacier ice as measured by borehole closure rates. Reviews of Geophysics and Space Physics, Vol. 15, No. 1, p. 47-55.

Souchez, R. A., and others. 1973. Refreezing of interstitial water in a subglacial cavity of an Alpine glacier as indicated by the chemical composition of ice, by R. A. Souchez, R. D. Lorrain, and M. M. Lemmens. Fournal of Glaciology, Vol. 12, No. 66, p. 453-59.

Spencer, J. W. 1887 . Glacial erosion in Norway and in high latitudes. Transactions of the Royal Society of Canada, Vol. 5, Sect. 4, p. 89-98. 

Swinzow, G. K. 1962. Investigation of shear zones in the ice sheet margin, Thule area, Greenland. Fournal of
Glaciology, Vol. 4, No. 32, p. 21 $5^{-29}$.

Theakstone, W. H. 1965 . Subglacial observations at Østerdalsisen, Svartisen. Norsk Geografisk Tidsskrift, Bd. 20, Ht. I-2, P. 38-43.

Theakstone, W. H. 1966. Deformed ice at the bottom of Østerdalsisen, Norway. Journal of Glaciology, Vol. 6, No. 43 , p. 19-21.

Theakstone, W. H. 1967. Basal sliding and movement near the margin of the glacier Østerdalsisen, Norway. Journal of Glaciology, Vol. 6, No. 48, p. 805-16.

Vivian, R. A., and Bocquet, G. 1973. Subglacial cavitation phenomena under the Glacier d'Argentière, Mont Blanc, France. Fournal of Glaciology, Vol. I2, No. 66, p. 439-5I.

Waeber, M. I943. Observations faites au Glacier de Tré-la-Tête à l'occasion de l'aménagement d'une prise. d'eau sous-glaciaire. Revue de Géographie Alpine, Tom. 30-31, p. 319-43. 